\title{
IRRIGATION MANAGMENTAND THE PRODUCTION OF SORGHUM UNDER CALCAREAUS SOIL
}

\author{
Gehan G. Abdel Ghany ${ }^{1}$ M.Y. El-Ansary ${ }^{2}$ M.A. Awad ${ }^{3}$ A.M. Gaber ${ }^{4}$
}

\section{ABSTRACT}

In general, irrigation by surface methods is the most common to supply crops with frequent application of water. Pressurized irrigation systems have been introduced in Egypt to develop new irrigation technology suited to limited water supply as well as to specific topographic and soil conditions. In this study, a field experiment was carried out in the Agricultural Experimental Station of the Desert Research Center, Maryut, Alex. Governorate during the two successive seasons of 2006 and 2007 .Five methods of irrigation were studied: , gated pipe(GP), surface drip irrigation, one line of drippers for one line of plants(D1:1), surface drip irrigation, one line of drippers for two lines of plants( D1:2 ), sub surface drip irrigation, one line drippers for one line of plants (SD1:1) and sub-surface drip irrigation, one line of drippers for two lines of plants (SD1:2). The irrigation methods were conducted under three water quantities $\left(100 \%, 70 \%\right.$ and50\%) of reference $E T_{O}$ calculated by modified Penman- Montieth equation, with two soil water depletion levels (30\% and 50\%) of available water. The statistical analysis revealed highly significant increases in all the studied parameters with increasing water quantities. The maximum fresh weights i.e. ,41.73,41.51and39.66 ton/fed./ were obtained with SD1:1,D1:1and GP, respectively under water quantity 100\% (Q1) and soil water depletion $30 \%$ ( D1), in the year 2006 while the maximum dry masses of 8.23,8.2and 7.9 ton/fed. Respectively were achieved under SD1:1, D1:1and GP with Q1and D1 .In 2007, the maximum fresh masses were, 42.55, 41.85and 40.53 under D1:1, SD1:1 and GP, while the maximum dry weights were 8.4, 7.98 and 7.27 ton/fed respectively .under D1:1, GPand SD1:1 with Q1and D1. The study showed that water use efficiency decreased by increasing quantity of the applied water.

KW: WUE, Evapotranspiration, Sub-Surface Drip Irrigation (SDI), Drip Irrigation (DI), Gated Pipe (GP), Soil depletion.

\footnotetext{
i 1 Assistant researcher in Desert Research center ; 2, 3 Resp. Prof. Emt and Assoc. Prof., Ag. Eng. Dept., Fac. Ag., Benha U., and 4 Prof. Doctor of water requirement, Desert Research Center.
} 


\section{INTRODUCTION}

$\mathrm{W}$

ater is the most limiting factor for plant production in arid and semiarid regions, and when the source of water is limited, the demand for water increases and water management will become an essential practice used by farmers .The relationships between yield and water consumption were established and the preferred irrigation programs to be used with surface irrigation were developed(Tekinel et al.,1999), (Fischbach and Somerholder1971) found that an automatic surface irrigation system with gated pipe (GP) and reused system can be very efficient in applying irrigation water ( 91.9\% efficiency ). Micro irrigation has been developed rapidly since the early 1960 .Some advantages of micro irrigation include improved water management and yield, .greater control of applied water resulting in less water and nutrient loss through deep percolation. (Phene et al., 1987) demonstrated that significant yield increases in tomatoes were achieved with the use of high frequency subsurface drip irrigation (SDI) and precise fertility management. (Hutmacher et al.,1996) demonstrated that yield of alfalfa production increased upon using SDI system buried at a depth of $0.7 \mathrm{~m}$.Cotton yield has also been improved using SDI system (Smith et al.,1991) and (Ayars et al.,1998).Water use efficiency has been significantly improved through the use of subsurface drip irrigation SDI (Phene et al.1986b). The objective of this study is to improve water management ,irrigation efficiency and water use efficiency with gated pipe (GP), surface drip irrigation (DI) and subsurface drip(SDI) irrigation systems.

\section{MATERIALS AND METHODS}

Afield experiment was carried out in Maryout Agricultural Research Station (محطة التجارب الحقليى بمريوط, south west of Alexandria (elevation $12.75 \mathrm{~m}$, latitude $31^{\circ} 22 \mathrm{~N}$ and Longitude $29^{\circ} 27 \mathrm{E}$ ) during the two successive seasons 2006 and 2007.

The study was conducted under splet splet design with three replicates to evaluate the influence of pressurized irrigation systems (gated pipe, surface and subsurface drip irrigation) and water management practices 
represented by the applied water depth and water distribution uniformity on

1- Consumptive use,

2- Water use efficiency,

3 production of sorghum represented by yield and yield components under calcareous soil condition.

\section{Soils of the studied area.}

The area of study was represented by a soil profile from which five depths were sampled i.e. $(0-20,20-40,40-60,60-80$ and $80-100$ $\mathrm{cm})$. The soil samples were air dried, ground and sieved through a $2 \mathrm{~mm}$ screen to get the fine part of soil which is kept for analysis.

The chemical and physical properties of the collected soil samples were determined according to the standard methods outlined in the following: -Particle size distribution by the pipette method as described by (Klute, 1986).

- Particle density (dp) according to(Richards, 1954).

- Bulk density (db) by soil cores method according to (Richards, 1954).

- Porosity was calculated using the equation. Porosity\% $(\mathrm{n})=($ ( $\mathrm{dP}-\mathrm{db})$ ( dP) $) \times 100$.

- Calcium carbonate content was determined by Collin's calcimeter according to Richards (1954).

- PF curves and soil moisture retention at 0.33 (corresponding to soil field capacity) and 15 bar (corresponding to soil wilting point) were determined in the undisturbed soil cores using the pressure cooker and pressure membrane, respectively, according to Singh (1980) and results obtained are presented in Table (2).

- The filtration rate was determined by using the double ring infiltrometer as described by Kohneke (1980).

- Cationic and anionic composition, $\mathrm{p}^{\mathrm{H}}$ and EC of the soil saturation extract were determined according to Richards (1954) 
- Soil organic matter content was determined according to the method of Walklay and Black (Jackson, 1967)

- Caution exchange capacity was determined using

NaOAc_NH4OAC according Richards (1954). Exchangeable cautions were extracted using NH4 OAc method (Jackson, 1973) .and determined as outlined by Black (1965)

- Data set out in Tables (1, 2, 3 and 4) reveal that the studied soil is generally loamy - textured except for the surface $(0-20 \mathrm{~cm})$ and deepest $(80-100 \mathrm{~cm})$ layers which are of a sandy -loam texture. Total calcium carbonate content increased slightly with depth and ranged from $28.5 \%$ to $30.1 \%$. Also, the soil bulk density increased with depth and varied between 1.42 and $1.57 \mathrm{~g} / \mathrm{cm}^{3}$.

The soil reaction is moderately alkaline; where soil $\mathrm{pH}$ ranged from 7.5 to 7.7. Electrical conductivity of soil paste extract indicates that soil is slightly saline, where ECe values varied from 2.8 at $(40-60 \mathrm{~cm}$ depth) to $3.9 \mathrm{dSm}^{-1}$ at the surface layer. The soil saturation extract showed that $\mathrm{Na}^{+}$ and $\mathrm{Ca}^{2+}$ were the dominant cautions while $\mathrm{Cl}^{-}$was the dominant anion followed, by $\mathrm{SO}_{2-}$ and $\mathrm{HCO}_{3}{ }^{-}$.

Table (1) Some soil physical properties of the studied soil:

\begin{tabular}{|c|c|c|c|c|c|c|c|c|c|c|}
\hline \multirow{2}{*}{$\begin{array}{l}\text { Soil } \\
\text { depth } \\
\text { (cm.) }\end{array}$} & \multicolumn{4}{|c|}{ Particle size distribution $\%$} & \multirow{2}{*}{$\begin{array}{c}\text { Textural } \\
\text { class }\end{array}$} & \multirow{2}{*}{$\begin{array}{l}\text { Bulk } \\
\text { density } \\
\text { g.cm }{ }^{-3}\end{array}$} & \multirow{2}{*}{$\begin{array}{l}\text { Particle } \\
\text { density } \\
\text { g.cm-3 }\end{array}$} & \multirow{2}{*}{ Porosity $\%$} & \multicolumn{2}{|c|}{$\begin{array}{c}\text { Infiltration } \\
\text { Rate }\end{array}$} \\
\hline & $\begin{array}{l}\text { Coarse } \\
\text { sand }\end{array}$ & $\begin{array}{l}\text { Fine } \\
\text { sand }\end{array}$ & Silt & Clay & & & & & $\begin{array}{l}\mathrm{cm} \cdot \mathrm{h}^{-} \\
1\end{array}$ & class \\
\hline $0-20$ & 3.10 & 49.10 & $\begin{array}{c}32.1 \\
0\end{array}$ & $\begin{array}{c}19.4 \\
0\end{array}$ & S.L. & 1.42 & 2.28 & 37.72 & & \\
\hline $20-40$ & 3.60 & 44.00 & $\begin{array}{c}30.3 \\
0\end{array}$ & $\begin{array}{c}22.1 \\
0\end{array}$ & L. & 1.44 & 2.26 & 36.28 & & \\
\hline $40-60$ & 4.00 & 42.40 & $\begin{array}{c}29.6 \\
0\end{array}$ & $\begin{array}{c}24.0 \\
0\end{array}$ & L. & 1.57 & 2.25 & 30.22 & 4.35 & 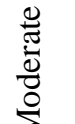 \\
\hline $60-80$ & 2.90 & 40.10 & $\begin{array}{c}30.9 \\
0\end{array}$ & $\begin{array}{c}25.1 \\
0\end{array}$ & L. & 1.56 & 2.3 & 32.17 & & \\
\hline $80-100$ & 1.60 & 37.50 & $\begin{array}{c}34.3 \\
0\end{array}$ & $\begin{array}{c}26.6 \\
0\end{array}$ & S.L. & 1.56 & 2.3 & 32.17 & & \\
\hline
\end{tabular}




$$
\begin{aligned}
& \text { S.L =sandy loam } \\
& \mathrm{L}=\text { loamy }
\end{aligned}
$$

Table (2): Soil moisture retention curve (pf) (w/w \%) of the studied soil.

\begin{tabular}{|l|l|l|l|l|l|l|l|l|l|l|}
\hline \multirow{2}{*}{$\begin{array}{l}\text { Soil } \\
\text { depth } \\
(\mathrm{cm} .)\end{array}$} & 0.001 & 0.10 & 0.33 & 0.66 & 1.00 & 5.00 & 10.00 & 15.00 & $\begin{array}{c}\text { Available } \\
\text { soil water } \\
(\%)\end{array}$ & $\begin{array}{c}\text { Available } \\
\text { soil } \\
\text { water } \\
(\mathrm{mm} / \mathrm{m})\end{array}$ \\
\hline $0-20$ & 50.42 & 27.38 & 26.32 & 23.37 & 20.65 & 17.24 & 15.11 & 13.23 & 13.09 & 185.8 \\
\hline $20-40$ & 50.49 & 27.51 & 26.61 & 23.29 & 20.72 & 17.31 & 15.22 & 13.47 & 13.14 & 189.2 \\
\hline $40-60$ & 50.54 & 28.11 & 27.23 & 23.41 & 20.83 & 17.35 & 15.37 & 14.03 & 13.20 & 207.2 \\
\hline $60-80$ & 50.63 & 28.26 & 27.43 & 23.83 & 20.75 & 17.51 & 15.43 & 14.21 & 13.22 & 206.2 \\
\hline $80-100$ & 50.63 & 28.26 & 27.43 & 23.83 & 20.75 & 17.51 & 15.43 & 14.21 & 13.22 & 206.2 \\
\hline
\end{tabular}

\begin{tabular}{|c|c|c|c|c|c|c|c|c|c|c|c|}
\hline \multirow{2}{*}{$\begin{array}{l}\text { Soil } \\
\text { depth } \\
\text { (cm.) }\end{array}$} & \multirow{2}{*}{$\begin{array}{c}\text { Organic } \\
\text { matter } \\
\%\end{array}$} & \multirow{2}{*}{$\begin{array}{c}\mathrm{pH} \\
\text { (soil water } \\
\text { suspension) }\end{array}$} & \multirow{2}{*}{$\begin{array}{c}\mathrm{EC}_{\mathrm{c}} \mathrm{dS} \\
/ \mathrm{m}\end{array}$} & \multicolumn{4}{|c|}{ Cations $\left(\mathrm{m} \mathrm{mol} \mathrm{L}^{-1}\right)$} & \multicolumn{4}{|c|}{ Anions (m molcL ${ }^{-}$) } \\
\hline & & & & $\mathrm{Na}+$ & $\mathrm{K}+$ & $\mathrm{Ca}^{2+}$ & $\mathrm{Mg}^{2+}$ & $\mathrm{CO}^{2-}$ & $\mathrm{HCO}^{-}$ & $\mathrm{Cl}^{-}$ & $\mathrm{SO}_{4}^{2-}$ \\
\hline $0-20$ & 0.63 & 7.6 & 4.09 & $\begin{array}{c}22.7 \\
3\end{array}$ & $\begin{array}{c}1.3 \\
2\end{array}$ & $\begin{array}{c}10.5 \\
3\end{array}$ & 6.21 & 0 & 2.73 & 29.67 & 8.49 \\
\hline $20-40$ & 0.32 & 7.6 & 3.48 & $\begin{array}{c}20.0 \\
4\end{array}$ & $\begin{array}{c}1.4 \\
4\end{array}$ & 8.32 & 5.02 & 0 & 2.75 & 25.53 & 6.54 \\
\hline $40-60$ & 0.49 & 7.5 & 3.09 & $\begin{array}{c}18.7 \\
4\end{array}$ & $\begin{array}{c}1.5 \\
9\end{array}$ & 6.68 & 3.89 & 0 & 4.46 & 21.49 & 4.95 \\
\hline $60-80$ & 0.58 & 7.6 & 3.28 & $\begin{array}{c}21.1 \\
5\end{array}$ & $\begin{array}{c}1.0 \\
0\end{array}$ & 7.51 & 3.10 & 0 & 4.22 & 22.92 & 5.62 \\
\hline $\begin{array}{l}80- \\
100\end{array}$ & 0.33 & 7.7 & 3.47 & $\begin{array}{c}23.5 \\
2\end{array}$ & $\begin{array}{c}0.6 \\
0\end{array}$ & 8.40 & 2.14 & 0 & 3.36 & 24.77 & 6.53 \\
\hline
\end{tabular}

\section{Table (3): Some chemical properties of the soil under study}


Table (4): $\mathrm{CaCO}_{3}$ content, $\mathrm{CEC}$ and exchangeable Cations of the soil under study

\begin{tabular}{|l|l|l|l|l|l|l|}
\hline \multirow{2}{*}{$\begin{array}{l}\text { Soil } \\
\text { depth } \\
(\mathrm{cm} .)\end{array}$} & \multirow{2}{*}{$\mathrm{CaCo}^{3}$} & \multirow{2}{*}{$\begin{array}{l}\mathrm{CEC} \\
\mathrm{c} \mathrm{molc} \mathrm{kg}\end{array}$} & & \multicolumn{4}{|l|}{ Exchangeable Cations $(\mathrm{c}$ molc kg-1 } \\
\cline { 5 - 8 } & & & $\mathrm{NA}^{+}$ & $\mathrm{K}^{+}$ & $\mathrm{Ca}^{2+}$ & $\mathrm{Mg}^{2+}$ \\
\hline $0-20$ & 28.50 & 20.06 & 7.15 & 1.42 & 8.36 & 2.93 \\
\hline $20-40$ & 28.90 & 19.42 & 7.11 & 1.31 & 8.13 & 2.87 \\
\hline $40-60$ & 29.80 & 19.62 & 7.48 & 1.37 & 7.87 & 2.9 \\
\hline $60-80$ & 29.90 & 20.24 & 8.07 & 1.23 & 8.21 & 2.71 \\
\hline $80-100$ & 30.10 & 20.24 & 8.07 & 1.23 & 8.21 & 2.71 \\
\hline
\end{tabular}

\section{2- Meteorological data.}

Data in Table(5) through the summer season (Jun to Oct.) indicates that the average maximum air temperature value ranges between $27.00 c^{\circ}$ and $31.2 \mathrm{c}^{\circ}$ while the minimum temperature value ranges from $17 \mathrm{c}^{\circ}$ in Oct to $24.4 c^{\circ}$ in September .

The relative humidity is nearly high and reaches its maximum value in July $70.0 \%$

The sunshine hours vary from $12.00 \mathrm{~h}$ in July to $9.2 \mathrm{~h}$ in October while the wind velocity ranges from $2.81 \mathrm{~m} / \mathrm{sec}$ in October to $3.92 \mathrm{~m} / \mathrm{sec}$ in July.

The total rainfalls occurred through September and October months were 5.58 and $59.94 \mathrm{~mm}$, respectively

Table (5): Meteorological data of Maryut area as average of 30 years

\begin{tabular}{|l|l|l|l|l|l|l|l|l|l|l|l|l|l|}
\hline Element & Jan & Feb & Mar & April & May & June & July & Aug & Sep & Oct & Nov & Dec & Year \\
\hline Max. Tep. & 17.50 & 17.50 & 22.50 & 25.00 & 27.50 & 30.00 & 30.00 & 32.50 & 30.00 & 27.50 & 23.00 & 20.00 & 25.25 \\
\hline Min. Tep. & 7.50 & 7.50 & 12.50 & 12.50 & 15.00 & 20.00 & 22.50 & 22.50 & 20.00 & 17.50 & 14.00 & 10.00 & 15.13 \\
\hline Avg. Tep. & 12.50 & 12.50 & 17.50 & 17.50 & 21.25 & 25.0 & 26.25 & 27.50 & 25.00 & 22.50 & 18.50 & 1500 & 20.19 \\
\hline Mean RH & 70.00 & 70.00 & 60.00 & 60.00 & 60.00 & 60.00 & 70.00 & 70.00 & 70.00 & 70.00 & 70.00 & 70.00 & 66.67 \\
\hline $\begin{array}{l}\text { Wind speed } \\
\text { (m/sec) }\end{array}$ & 3.97 & 3.97 & 4.10 & 3.87 & 3.60 & 3.60 & 3.92 & 3.60 & 3.28 & 2.81 & 3.04 & 3.69 & 3.62 \\
\hline Sunshine( hour) & 6.60 & 7.60 & 8.30 & 9.20 & 10.40 & 11.90 & 12.00 & 11.30 & 10.40 & 9.20 & 7.40 & 6.50 & 9.23 \\
\hline Rs (MJ/m2/d) & 11.60 & 15.00 & 18.80 & 22.40 & 25.30 & 27.90 & 27.80 & 25.70 & 22.20 & 17.70 & 12.90 & 10.90 & 19.85 \\
\hline G (MJ/m2/d) & 0.35 & 0.00 & 0.70 & 0.18 & 0.35 & 0.53 & 0.18 & 0.18 & 0.35 & 0.35 & 0.56 & 0.49 & 0.00 \\
\hline Ra - G & 4.75 & 6.72 & 8.87 & 12.11 & 14.05 & 15.97 & 15.32 & 15.32 & 12.86 & 9.10 & 5.95 & 4.39 & 10.55 \\
\hline Total rain (mm) & 50.00 & 25.00 & 15.00 & 5.00 & 1.00 & 0.00 & 0.00 & 0.00 & 1.00 & 10.00 & 20.00 & 35.00 & 162.0 \\
\hline S =Kpa / oC & 0.095 & 0.95 & 0.116 & 0.126 & 0.165 & 0.189 & 0.199 & 0.215 & 0.189 & 0.165 & 0.126 & 0110 & 0.149 \\
\hline
\end{tabular}


RH: relative humidity \%

$\mathrm{Ra}$ : net radiation at the crop surface $\left(\mathrm{MJ} \cdot \mathrm{m}^{-2}\right.$. day $\left.{ }^{-1}\right)$

G: soil heat flux density (MJ.m ${ }^{-2}$.day ${ }^{-1}$ )

S: slope of the saturation vapor pressure curve (1.08:1.34) average1.26

Rs: solar radiation in equivalent evaporation ( $\mathrm{mm} /$ day)

\section{3- Irrigation systems.}

Three irrigation systems were used to irrigate the grown plant. The system consists of a diesel pump $\left(18 \mathrm{~m}^{3} / \mathrm{h}\right.$, flow rate), it takes water from open subsurface tank $\left(75 \mathrm{~m}^{3}\right)$ capacity through two filter units, the first one is a screen (130 meshes) and the other is a gravel filter.

The filtration system is controlled, by safety valve, relief valve, four control valves, pressure regulator unit, flow meter unit, air tank (balloon) unit, $6.4 \mathrm{~mm}$ pressure meter.

The manifold is $50-\mathrm{mm}$ PVC pipeline with $50 \mathrm{~mm}$ end plug for flushing. The drippers (emitters) were with a flow rate of $4 \mathrm{~L} / \mathrm{h}$ (GR) installed in $16 \mathrm{~mm}$ polyethylene laterals.

The filtration system is controlled, by safety valve, relief valve, four control valves, pressure regulator unit, flow meter unit, air tank (balloon) unit, $6.4 \mathrm{~mm}$ pressure meter.

The manifold is $50-\mathrm{mm}$ PVC pipeline with $50 \mathrm{~mm}$ end plug for flushing. The drippers (emitters) were with a flow rate of $4 \mathrm{~L} / \mathrm{h}(\mathrm{GR})$ installed in $16 \mathrm{~mm}$ polyethylene laterals.

\begin{tabular}{|c|c|c|c|c|}
\hline \multicolumn{5}{|l|}{$\begin{array}{l}\text { CUNTROL } \\
\text { HEAD }\end{array}$} \\
\hline & & \multirow{4}{*}{ Control } & [1:] & [1:] \\
\hline & & & $5 \mathrm{D} 1: 1$ & $\$ D 1: 1$ \\
\hline & & & D1:? & D1:? \\
\hline 0302 & & & $201: 5$ & $5[1: 2$ \\
\hline 8301 & & & & \\
\hline QอDe & $S D 1: P$ & SDI:? & snde & $s 01: 2$ \\
\hline Q201 & Dy:2 & D1:? & D1: $\hat{2}$ & D1:? \\
\hline Q]D2 & SI1:1 & SD1; & s[1:1 & $\$ D 1 ; 1$ \\
\hline Q]D1 & D):1 & D1:1 & D1:1 & D1:1 \\
\hline
\end{tabular}

Fig (1): The irrigation system and treatments. 


\section{3-1 - Surface drip irrigation (two techniques)}

a) One line of drippers (GR $41 / \mathrm{hr}$ and the distance between drippers is $50 \mathrm{~cm}$ ) for one line of plants (D1:1).

b) One line of drippers for two lines of plants (D1:2).

\section{3- 2 - Subsurface drip irrigation.}

a) One line of drippers (GR $41 / \mathrm{hr}$ and the distance between drippers is $30 \mathrm{~cm}$ ) for one line of plants (SD1:1).

b) One line of drippers for two lines of plants (SD1:2).

\section{3- 3 - Gated pipes (GP).}

$160 \mathrm{~mm}$ in diameter aluminum pipes were used with gates located at 70 $\mathrm{cm}$ spacing. The one gate discharge is $0.5 \mathrm{~L} / \mathrm{s}$

The system consists of a diesel pump $\left(18 \mathrm{~m}^{3} / \mathrm{h}\right.$, flow rate), it takes water from open subsurface tank $\left(\mathrm{c}^{7} \mathrm{~m}^{3}\right)$ capacity through two filter units, the first one is a screen (130 mesh) and the other is a gravel filter .

\section{4- Measuring of discharge $(Q)$.}

According to Awady, (1978) the discharge was measured by a direct method using volume and time. This is one of the simplest and most accurate methods, the equation is $Q=\mathrm{v} / \mathrm{t}$

Where

$\mathrm{Q}=$ discharge in $(\mathrm{L} / \mathrm{h})$

$\mathrm{V}=$ volume in (liter)

$\mathrm{t}=$ time (hour)

\section{RESULTS AND DESCUTION}

1- Effect was studied of soil water depletion on fresh and dry masses (ton/fed.) of first and second cuts of the sorghum plants grown in the two studied seasons.

2- Results in illustrated graphically in Figs. 2 and 3 indicate that irrigation under $30 \%$ soil water depletion resulted in significantly higher values for fresh and dry weights of the sorghum plants in both cuts of both the two seasons of cultivation These results agree with those of Byer and. Mcphphrsoh (1975),.Eck(1986)and Hawell et al. (1995) 


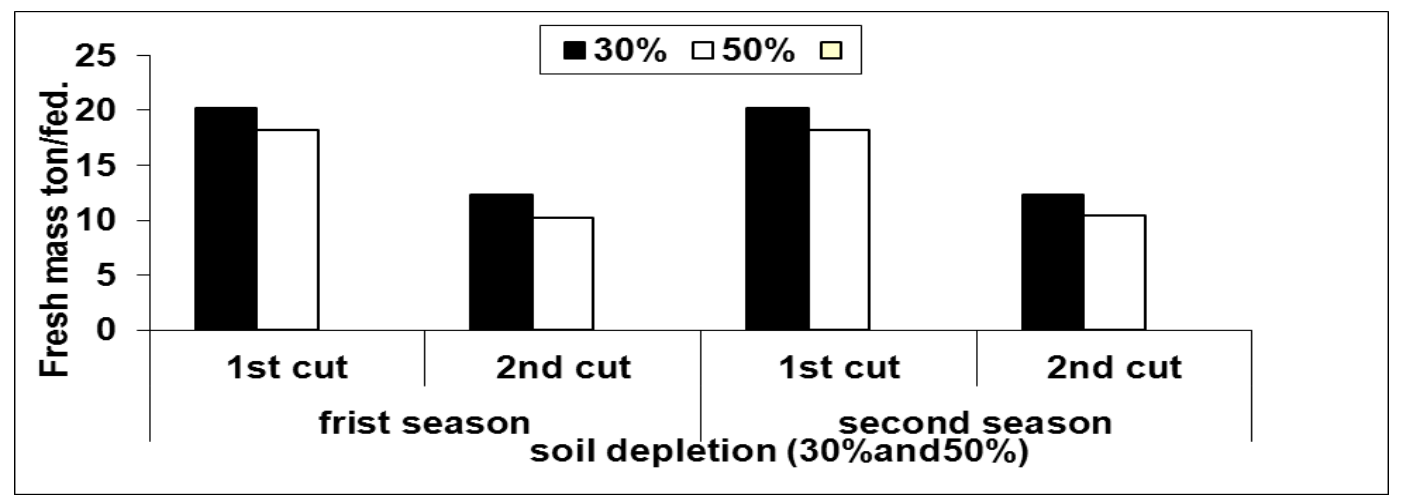

Fig (2): Effect of soil water depletion on fresh mass (ton/fed.) of first and second cuts of the sorghum grown in the two studied seasons

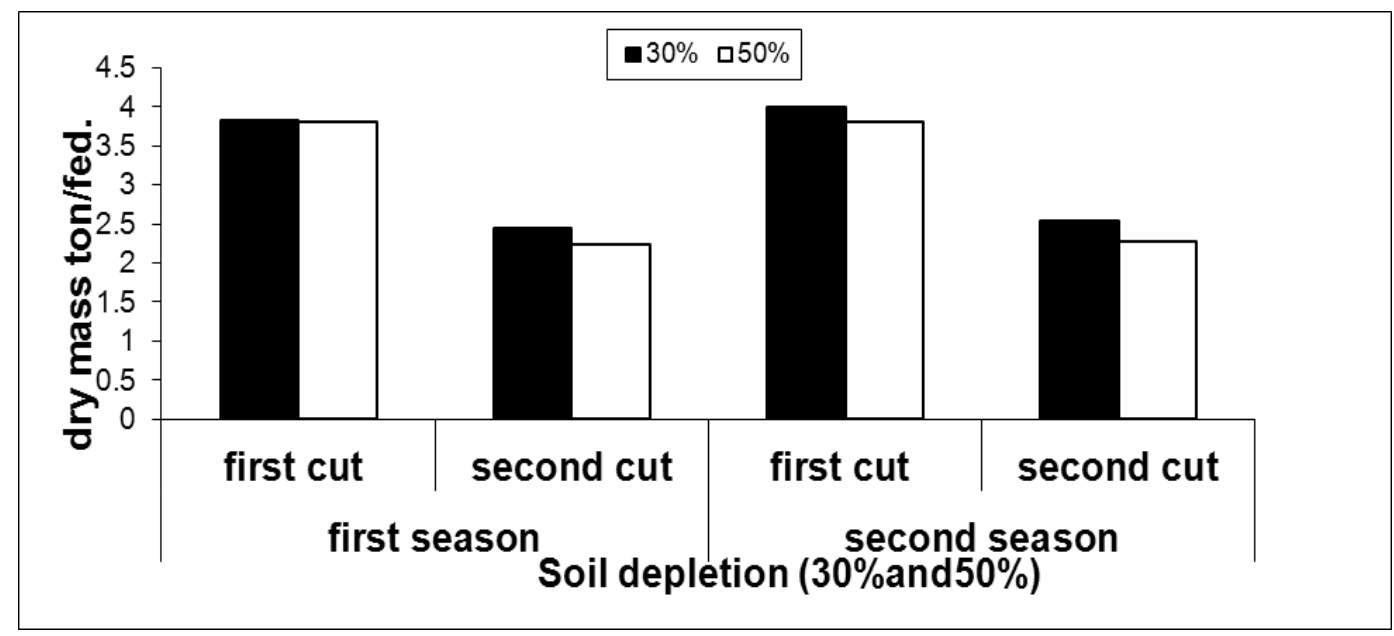

Fig (3): Effect of soil water depletion on dry mass (ton/fed.) of first and second cuts of the sorghum grown in the two studied seasons.

3- Effect of irrigation water quantity on fresh and dry masses (ton/fed.) of first and second cuts of the sorghum grown in the two seasons.

Fig (4 and 5) indicate that water quantities had significant effects on fresh and dry weights of the first and second cuts of the sorghum plants grown in the two seasons. The highest values of yield were noticed under the applied irrigation water quantity (100\%) of reference evapotranspiration $\left(\mathrm{ET}_{\mathrm{O}}\right)$.These results stand in well agreement with those of (Neelan and Rajput, 2007) who found that irrigation levels resulted in significant differences in both years on yield and its component 


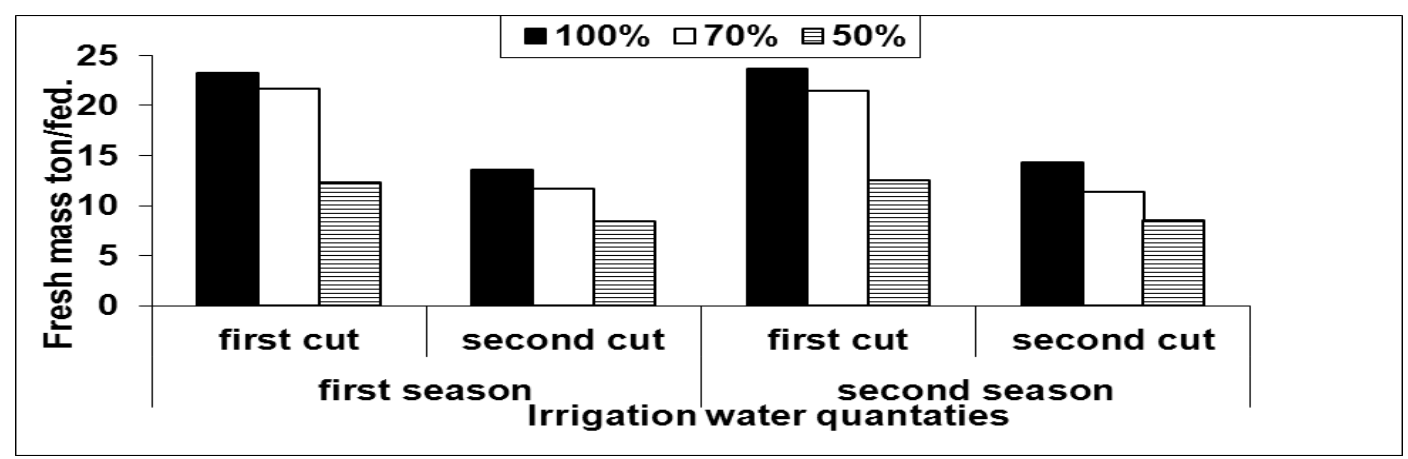

Fig (4): Effect of irrigation water quantity on fresh mass (ton/fed.) of the first and second cuts at the two studied seasons

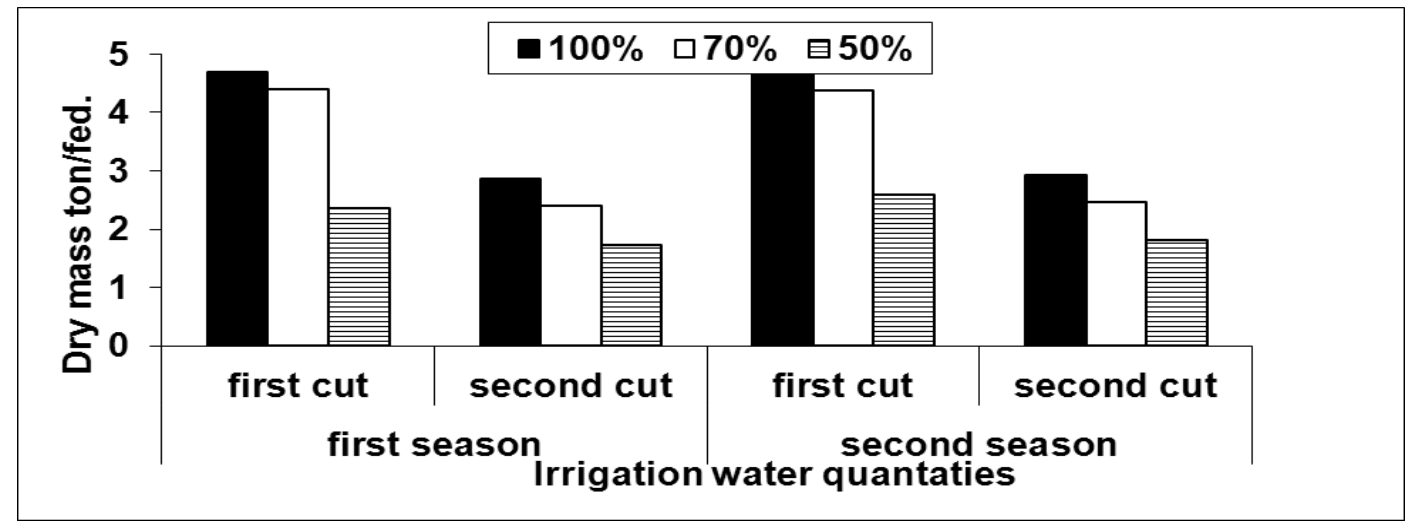

Fig (5): Effect of irrigation water quantity on dry mass (ton/fed.) of the first and second cuts of the sorghum plants in the two studied seasons. 4- Effect of the irrigation system on fresh and dry masses (ton/fed.) of the first and second cuts of the sorghum plants in the two studied seasons.

Fig (6) indicates that non of the used irrigation methods (surface and subsurface drip irrigations) could result in a significant difference on yield. However SD1:1 method resulted in higher fresh weight than GP, D1:2and SD1:2, for first cut in season 2006 .On the other hand, D1:1 resulted in the highest yields in the second season for both the first and second cuts, D1:1 resulted in the highest dry weight for the first cut, where as SD1:1 resulted in the highest dry yield of the second cut. The same results were noticed at the second season.These results agree with those of (Phene et al., 1987) who demonstrated significant yield increases 
with the use of high frequency SDI. (Hutmatcher et al., 1996) demonstrated yield increases in alfalfa production using SDI.

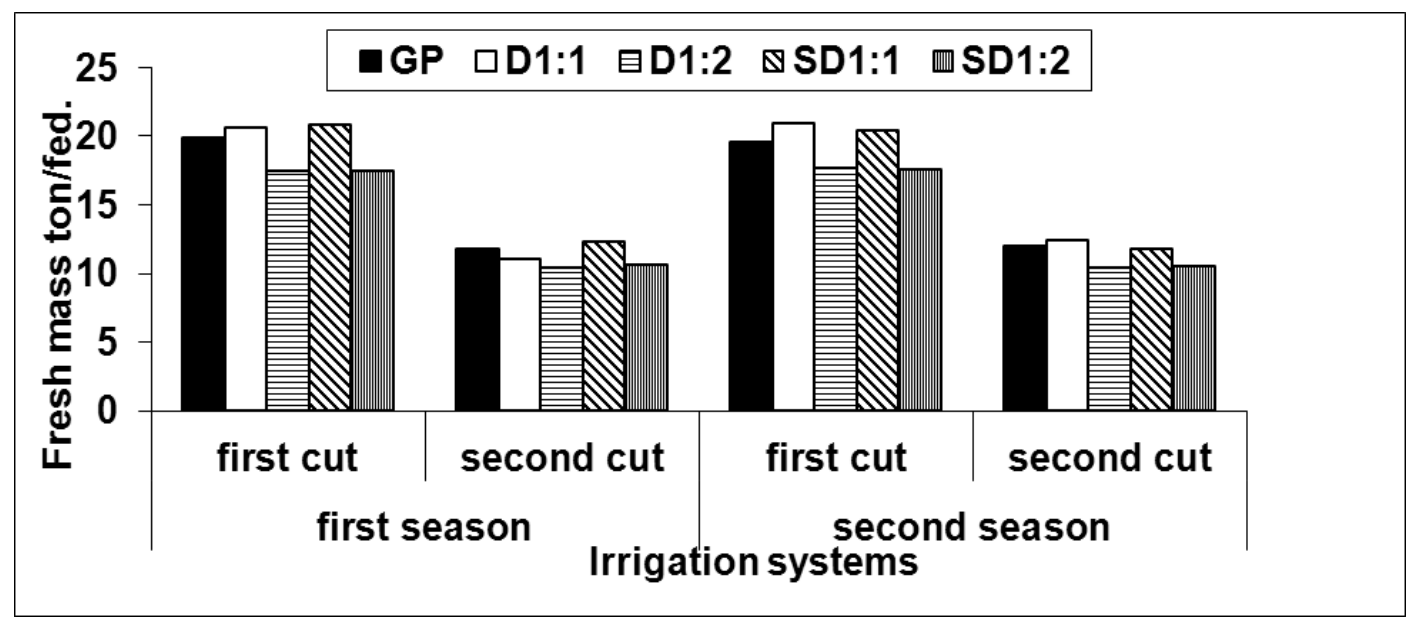

Fig (6): Effect of irrigation system on fresh mass (ton/fed.) of the first and second cuts of sorghum grown in the two studied seasons

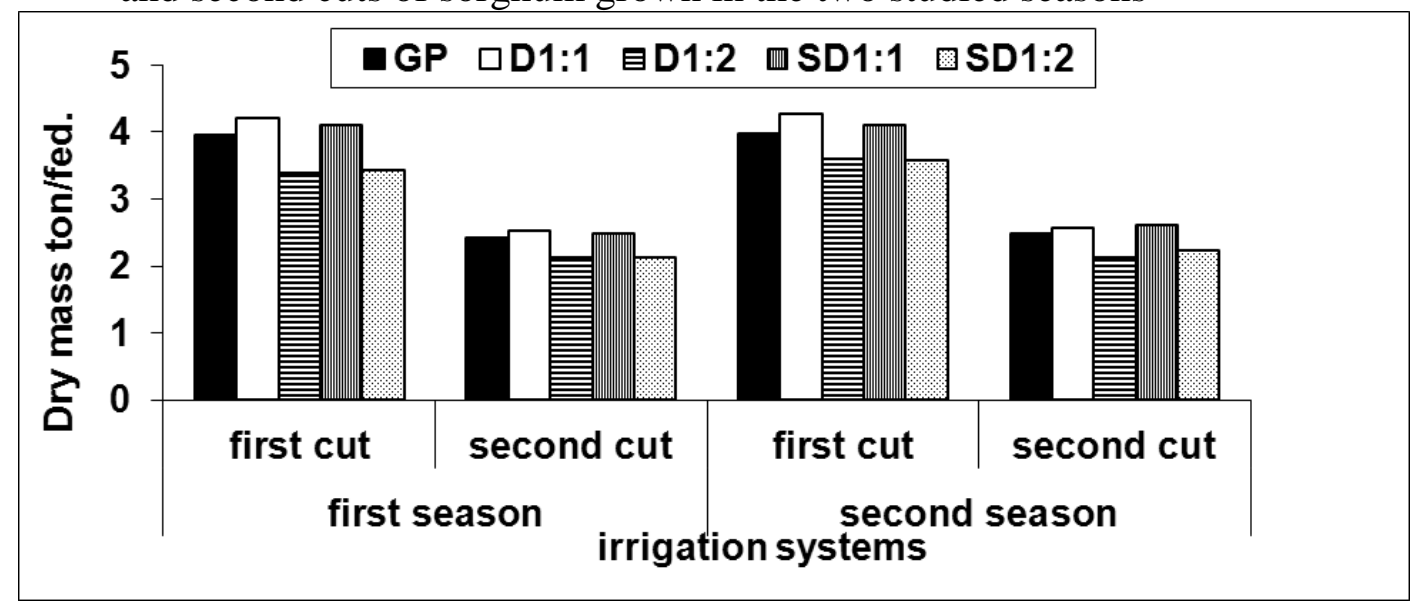

Fig (7): Effect of irrigation system on dry mass (ton/fed.) of the first and second cuts of sorghum grown in the two studied seasons.

5- Effect of interaction between soil water depletion and irrigation water quantity on fresh and dry masses (ton/fed.) of first and second cuts in the two studied seasons 
Data of interaction effect between soil water depletion and water quantities on fresh and dry weights at the two studied seasons indicated that, increasing water quantities together with $30 \%$ soil water depletion resulted in highly significant increases in both fresh and dry yields of the $1^{\text {st }}$ and $2^{\text {nd }}$ cuts in both the two successive cultivation seasons. On the other hand decreasing applied water quantities with increasing soil water depletion caused fresh and dry weights of the first and second cuts in the two successive seasons to decrease .These results coincide with those of Eck (1986)

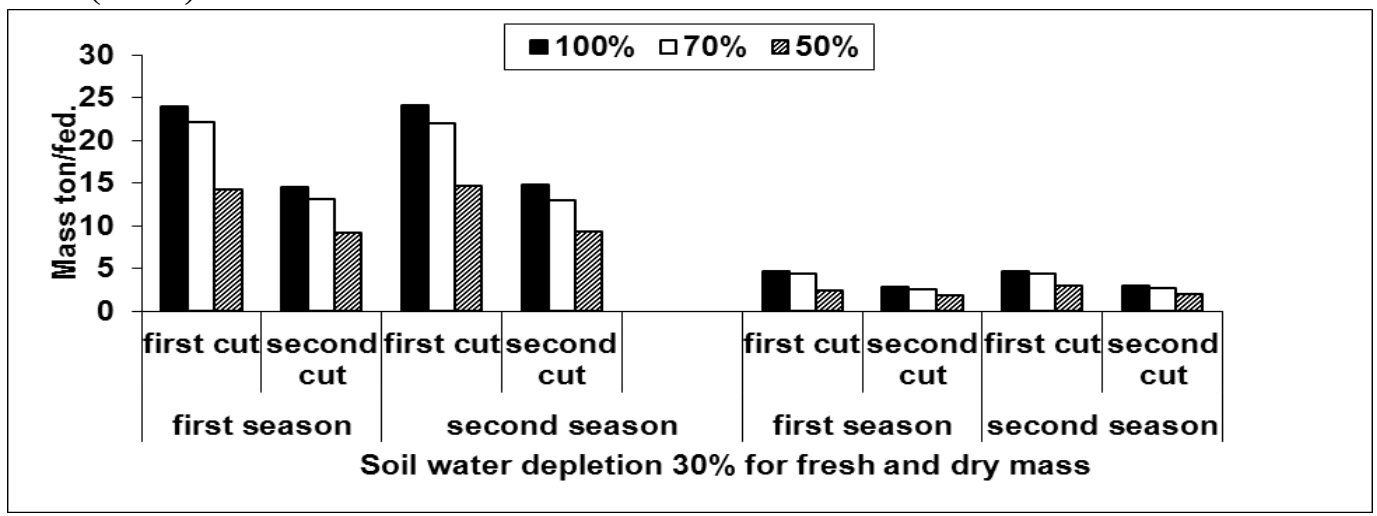

Fig(8):Effect of interaction between soil water depletion (30\%) and irrigation water quantity on fresh and dry mass (ton/fed.) of the first and second cuts of sorghum grown the two successive seasons.

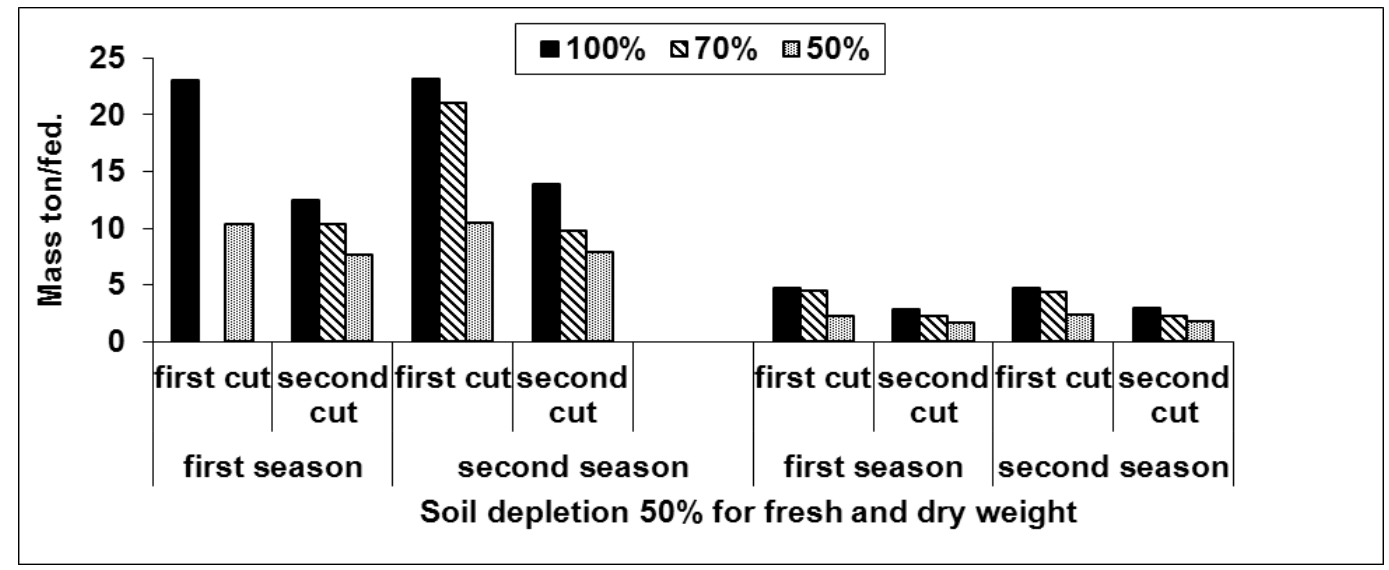

Fig(9):Effect of interaction between soil water depletion (50\%) and irrigation water quantity on fresh and dry mass (ton/fed.) of the first and second cuts of sorghum grown in the two successive seasons. 


\section{6- Effect of interaction between soil water depletion and irrigation} system on fresh and dry mass (ton/fed.) of the first and second cuts of sorghum grown in the two successive seasons

Data presented in Table (11) and illustrated graphically in Figs. (10) and (11) reveal the interaction effect between soil water depletion and irrigation systems on fresh and dry weights of the first and second cuts in both studied seasons. The interaction between soil water depletion $30 \%$ and the SD1:1 system resulted in the maximum values of both fresh weights of the two cuts in the first seasons .However, D1:1 system resulted in the highest fresh weight values of the first and second cuts in the second seasons beside of the highest dry weight of the first and second cuts in the first and second seasons. The results obtained herein are in agreement with those of (Eck, 1986)

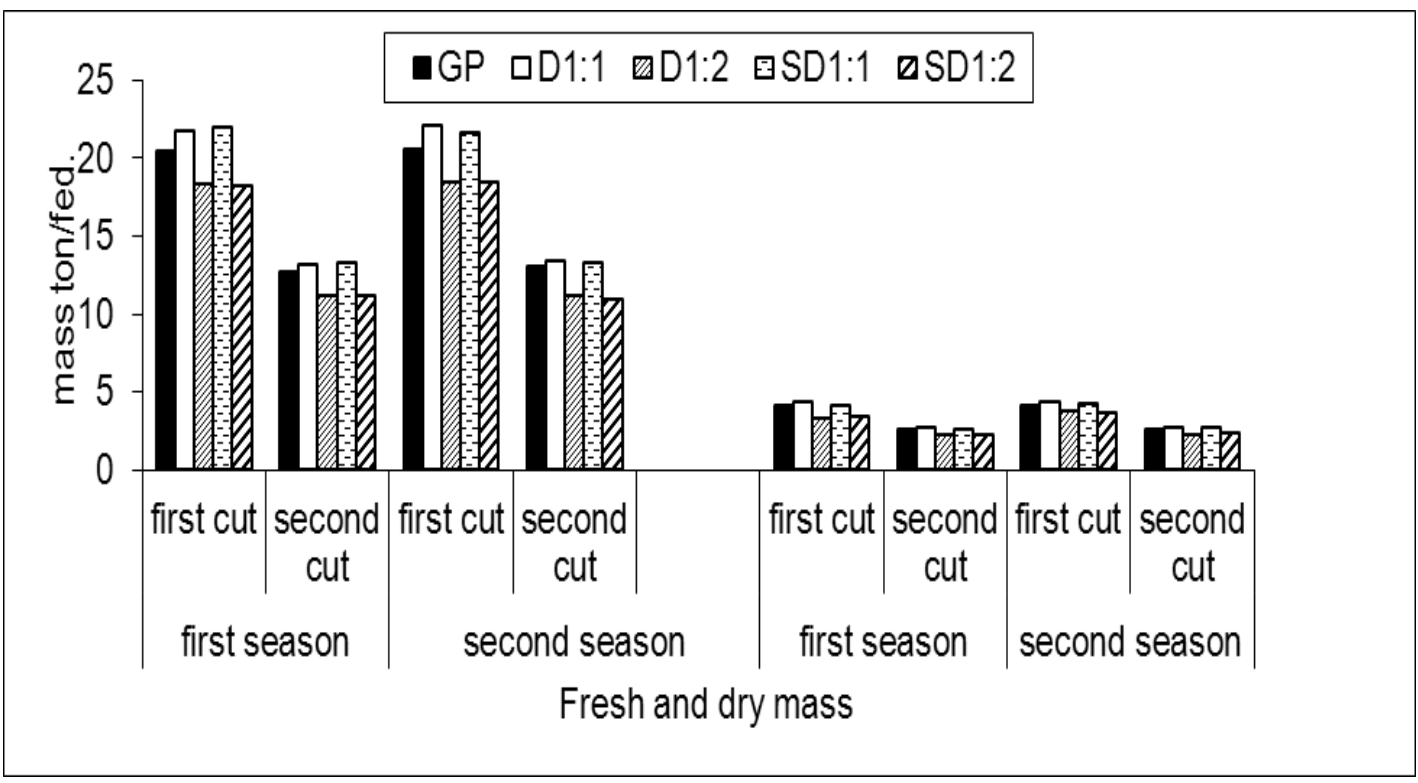

Fig (10): Effect of interaction between soil water depletion (30\%) and irrigation system on fresh and dry masses (ton/fed.) of the first and second cuts of the sorghum grown in the two seasons 


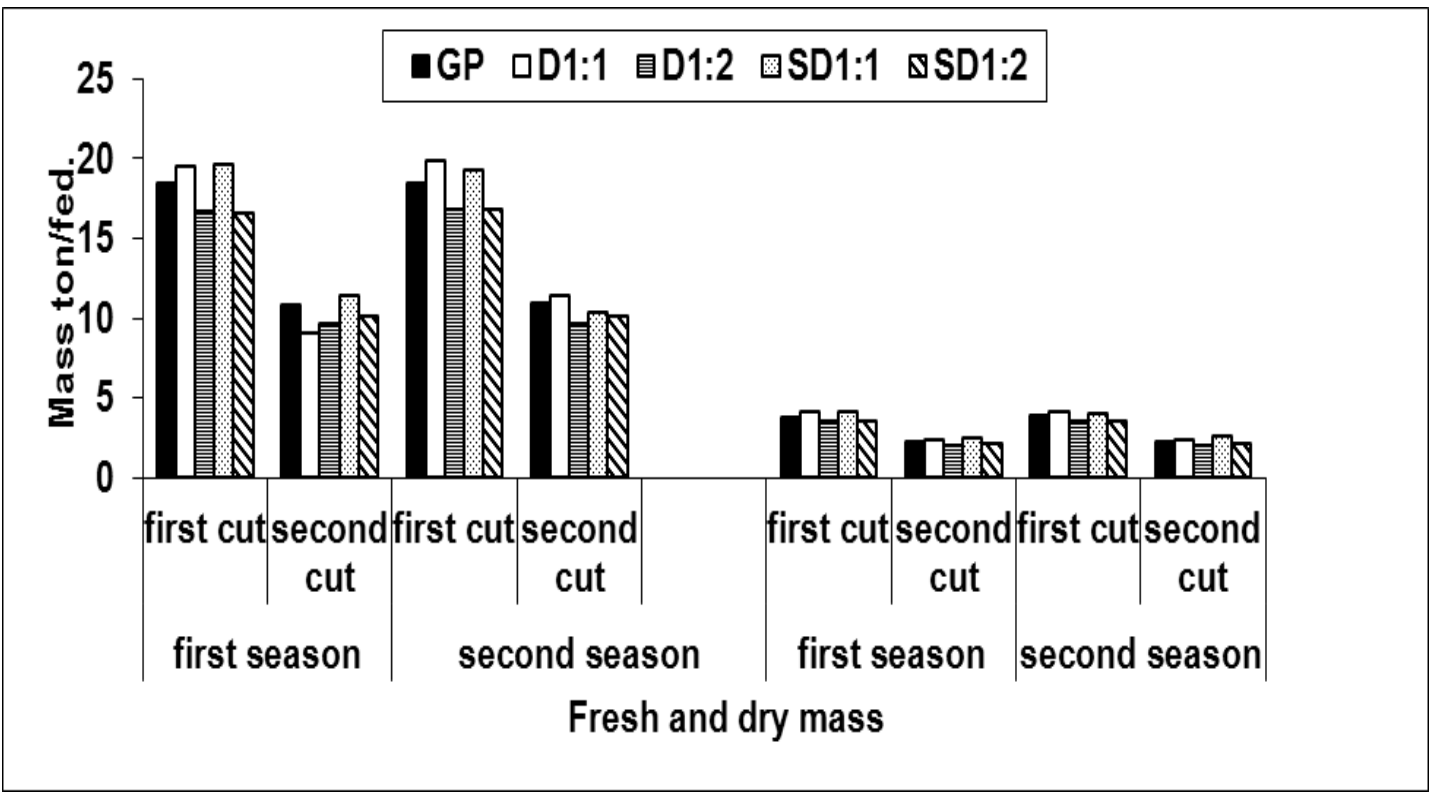

Fig (11): Effect of interaction between soil water depletion (50\%) and irrigation system on fresh and dry masses (ton/fed.) of the first and second cuts of the sorghum grown in the two seasons

7- Effect of the interaction between irrigation water quantity and irrigation system on fresh and dry masses (ton/fed.) of the first and second cuts of the sorghum grown in the two successive seasons

The interaction effects between water quantities and irrigation systems on fresh and dry weights for two cuts in the two seasons are presented in Table(6).The interaction between water quantity applied at 100\% ET and the irrigation systemsD1:1 and SD1:1 seemed to be of the highest significant effect on fresh and dry weights of the first and second cuts of sorghum grown in both the studied two seasons. 
Table (6): Effect of irrigation water quantity and irrigation system on fresh and dry masses (ton/fed.) of the first and second cuts at the two successive seasons.

\begin{tabular}{|c|c|c|c|c|c|c|c|c|c|}
\hline \multicolumn{2}{|c|}{ Treatments } & \multicolumn{4}{|c|}{ Fresh mass (ton/fed.) } & \multicolumn{4}{|c|}{ Dry mass (ton/fed.) } \\
\hline \multirow{2}{*}{$\begin{array}{c}\text { Water } \\
\text { use }\end{array}$} & \multirow{2}{*}{$\begin{array}{c}\text { Irri. } \\
\text { System }\end{array}$} & \multicolumn{2}{|c|}{$1^{\text {st }}$ season } & \multicolumn{2}{|c|}{$2^{\text {nd }}$ season } & \multicolumn{2}{|c|}{$1^{\text {st }}$ season } & \multicolumn{2}{|c|}{$2^{\text {nd }}$ season } \\
\hline & & $1^{\text {st }} \mathrm{cut}$ & $2^{\text {nd }} \mathrm{cut}$ & $1^{\text {st }}$ cut & $2^{\text {nd }}$ cut & $1^{\text {st }} \mathrm{cut}$ & $2^{\text {nd }}$ cut & $1^{\text {st }} \mathrm{cut}$ & $2^{\text {nd }}$ cut \\
\hline \multirow{5}{*}{$100 \%$} & GP & 23.72 & 14.63 & 23.83 & 14.98 & 4.79 & 2.94 & 4.77 & 3.01 \\
\hline & D $1: 1$ & 25.20 & 11.54 & 25.61 & 15.29 & 5.06 & 2.99 & 5.16 & 3.08 \\
\hline & D $1: 2$ & 21.65 & 13.00 & 21.87 & 13.01 & 4.20 & 2.62 & 4.39 & 2.61 \\
\hline & SD $1: 1$ & 25.14 & 15.04 & 25.18 & 15.09 & 5.05 & 3.14 & 5.05 & 3.20 \\
\hline & SD $1: 2$ & 21.66 & 13.64 & 21.71 & 13.48 & 4.37 & 2.76 & 4.36 & 2.73 \\
\hline \multirow{5}{*}{$70 \%$} & GP & 21.33 & 11.94 & 21.41 & 12.15 & 4.34 & 2.44 & 4.35 & 2.53 \\
\hline & D $1: 1$ & 22.93 & 12.43 & 22.96 & 12.53 & 4.66 & 2.55 & 4.66 & 2.60 \\
\hline & D $1: 2$ & 20.80 & 10.94 & 20.82 & 10.81 & 4.21 & 2.25 & 4.24 & 2.23 \\
\hline & SD $1: 1$ & 22.73 & 12.49 & 21.68 & 10.87 & 4.62 & 2.55 & 4.40 & 2.62 \\
\hline & SD $1: 2$ & 20.61 & 10.90 & 20.66 & 10.59 & 4.20 & 2.23 & 4.20 & 2.40 \\
\hline \multirow{5}{*}{$50 \%$} & GP & 13.39 & 8.85 & 13.41 & 8.92 & 2.73 & 1.88 & 2.80 & 1.90 \\
\hline & D $1: 1$ & 13.77 & 9.38 & 14.37 & 9.49 & 2.95 & 2.03 & 3.00 & 2.01 \\
\hline & D $1: 2$ & 9.98 & 7.17 & 10.24 & 7.32 & 1.73 & 1.52 & 2.14 & 1.56 \\
\hline & SD $1: 1$ & 14.37 & 9.36 & 14.41 & 9.43 & 2.62 & 1.72 & 2.84 & 2.01 \\
\hline & SD $1: 2$ & 9.96 & 7.29 & 10.26 & 7.35 & 1.71 & 1.40 & 2.13 & 1.57 \\
\hline \multirow{2}{*}{ LSD } & 0.05 & 1.64 & 1.34 & 1.87 & 1.42 & 0.32 & 0.24 & 0.41 & 0.31 \\
\hline & 0.01 & 2.19 & 1.79 & 2.49 & 1.89 & 0.42 & 0.32 & 0.54 & 0.41 \\
\hline
\end{tabular}

8- Effect of the interaction between soil water depletion, irrigation water quantity and irrigation system on fresh and dry masses (ton/fed.) of the first and second cuts of sorghum grown in the two seasons

The results presented in Table (7) indicated that the maximum values of fresh and dry masses were noticed under the interaction between 100\%ET and soil water depletion 30\% with D1:1 irrigation system. 
Table (7): Effect of soil water depletion, irrigation water quantity and irrigation system on fresh and dry masses (ton/fed.) of the first and second cuts at two seasons.

\begin{tabular}{|c|c|c|c|c|c|c|c|c|c|c|}
\hline \multicolumn{3}{|c|}{ Treatments } & \multicolumn{4}{|c|}{ Fresh mass (ton/fed.) } & \multicolumn{4}{|c|}{ Dry mass (ton/fed.) } \\
\hline \multirow[b]{2}{*}{ Depletion } & \multirow[b]{2}{*}{$\begin{array}{l}\text { Water } \\
\text { quantity }\end{array}$} & \multirow{2}{*}{$\begin{array}{c}\text { Irri. } \\
\text { system }\end{array}$} & \multicolumn{2}{|c|}{$1^{\text {st }}$ season } & \multicolumn{2}{|c|}{$2^{\text {nd }}$ season } & \multicolumn{2}{|c|}{$1^{\text {st }}$ season } & \multicolumn{2}{|c|}{$2^{\text {nd }}$ season } \\
\hline & & & $1^{\text {st }}$ cut & $\begin{array}{l}2^{\text {nd }} \\
\text { cut }\end{array}$ & $1^{\text {st }}$ cut & $\begin{array}{l}2^{\text {nd }} \\
\text { cut }\end{array}$ & $1^{\text {st }} \mathrm{cut}$ & $\begin{array}{l}2^{\text {nd }} \\
\text { cut }\end{array}$ & $1^{\text {st }}$ cut & $\begin{array}{l}2^{\text {nd }} \\
\text { cut }\end{array}$ \\
\hline \multirow{15}{*}{$30 \%$} & \multirow{5}{*}{$100 \%$} & GP & 24.14 & 15.52 & 24.43 & 16.10 & 4.80 & 3.06 & 4.79 & 3.19 \\
\hline & & D $1: 1$ & 25.82 & 15.69 & 26.02 & 16.32 & 5.09 & 3.11 & 5.16 & 3.24 \\
\hline & & D 1:2 & 21.97 & 13.16 & 22.21 & 13.26 & 4.00 & 2.60 & 4.38 & 2.60 \\
\hline & & SD 1:1 & 25.86 & 15.87 & 25.87 & 15.98 & 5.08 & 3.15 & 5.08 & 3.16 \\
\hline & & SD 1:2 & 21.95 & 12.92 & 21.98 & 12.58 & 4.32 & 2.57 & 4.33 & 2.50 \\
\hline & \multirow{5}{*}{$70 \%$} & GP & 22.00 & 13.16 & 22.08 & 13.27 & 4.36 & 2.64 & 4.37 & 2.75 \\
\hline & & D 1:1 & 23.50 & 13.67 & 23.50 & 13.72 & 4.66 & 2.76 & 4.66 & 2.83 \\
\hline & & D $1: 2$ & 21.11 & 12.64 & 21.15 & 12.43 & 4.17 & 2.57 & 4.20 & 2.55 \\
\hline & & SD 1:1 & 23.31 & 13.66 & 22.17 & 13.71 & 4.62 & 2.75 & 4.41 & 2.86 \\
\hline & & SD 1:2 & 20.93 & 12.49 & 21.00 & 11.91 & 4.16 & 2.52 & 4.18 & 2.86 \\
\hline & \multirow{5}{*}{$50 \%$} & GP & 15.35 & 9.62 & 15.42 & 9.76 & 3.10 & 1.99 & 3.11 & 2.02 \\
\hline & & D 1:1 & 15.82 & 10.26 & 16.70 & 10.31 & 3.33 & 2.12 & 3.36 & 2.13 \\
\hline & & D $1: 2$ & 11.80 & 7.71 & 11.99 & 7.77 & 1.67 & 1.59 & 2.42 & 1.61 \\
\hline & & SD 1:1 & 16.62 & 10.18 & 16.91 & 10.14 & 2.47 & 1.76 & 3.08 & 2.10 \\
\hline & & SD 1:2 & 11.82 & 8.03 & 12.11 & 8.09 & 1.66 & 1.36 & 2.42 & 1.68 \\
\hline \multirow{15}{*}{$50 \%$} & \multirow{5}{*}{$100 \%$} & GP & 23.29 & 13.73 & 23.23 & 13.87 & 4.78 & 2.81 & 4.75 & 2.84 \\
\hline & & D 1:1 & 24.59 & 7.38 & 25.20 & 14.25 & 5.04 & 2.88 & 5.16 & 2.93 \\
\hline & & D $1: 2$ & 21.33 & 12.83 & 21.53 & 12.76 & 4.39 & 2.64 & 4.41 & 2.62 \\
\hline & & SD 1:1 & 24.43 & 14.21 & 24.48 & 14.19 & 5.01 & 3.13 & 5.01 & 3.23 \\
\hline & & SD 1:2 & 21.38 & 14.37 & 21.44 & 14.38 & 4.41 & 2.94 & 4.39 & 2.96 \\
\hline & \multirow{5}{*}{$70 \%$} & GP & 20.65 & 10.72 & 20.73 & 11.03 & 4.31 & 2.23 & 4.32 & 2.30 \\
\hline & & D 1:1 & 22.36 & 11.18 & 22.42 & 11.33 & 4.66 & 2.33 & 4.66 & 2.37 \\
\hline & & D 1:2 & 20.49 & 9.25 & 20.48 & 9.18 & 4.24 & 1.93 & 4.27 & 1.91 \\
\hline & & SD 1:1 & 22.14 & 11.33 & 21.19 & 8.03 & 4.62 & 2.36 & 4.38 & 2.37 \\
\hline & & SD 1:2 & 20.29 & 9.32 & 20.32 & 9.26 & 4.23 & 1.94 & 4.23 & 1.94 \\
\hline & \multirow{5}{*}{$50 \%$} & GP & 11.43 & 8.08 & 11.39 & 8.09 & 2.37 & 1.76 & 2.48 & 1.77 \\
\hline & & D 1:1 & 11.71 & 8.50 & 12.03 & 8.66 & 2.56 & 1.94 & 2.64 & 1.89 \\
\hline & & D 1:2 & 8.15 & 6.62 & 8.49 & 6.86 & 1.78 & 1.45 & 1.86 & 1.50 \\
\hline & & SD 1:1 & 12.13 & 8.54 & 11.92 & 8.73 & 2.77 & 1.68 & 2.60 & 1.92 \\
\hline & & SD 1:2 & 8.10 & 6.55 & 8.40 & 6.61 & 1.77 & 1.43 & 1.83 & 1.46 \\
\hline \multirow{2}{*}{ LSD } & \multicolumn{2}{|c|}{0.05} & 2.32 & 1.90 & 2.64 & 2.01 & 0.45 & 0.34 & 0.57 & 0.44 \\
\hline & \multicolumn{2}{|c|}{0.01} & 3.09 & 2.53 & 3.52 & 2.68 & 0.59 & 0.46 & 0.76 & 0.59 \\
\hline
\end{tabular}


Table (8): Average WUE for sorghum crop (dry weight $\mathrm{kg} / \mathrm{m}^{3}$ )

\begin{tabular}{|c|c|c|c|c|c|c|}
\hline WQ & D & GP & D1:1 & D1:2 & SD1:1 & SD1:2 \\
\hline \multirow{2}{*}{ Q1 } & D1 & 3.32 & 3.86 & 3.19 & 3.73 & 3.61 \\
\cline { 2 - 7 } & D2 & 3.55 & 4.18 & 3.68 & 3.97 & 3.99 \\
\hline \multirow{2}{*}{ Q2 } & D1 & 4.29 & 4.84 & 4.39 & 4.86 & 4.48 \\
\cline { 2 - 7 } & D2 & 4.23 & 5.1 & 4.54 & 5.12 & 4.62 \\
\hline \multirow{2}{*}{ Q3 } & D1 & 4.17 & 4.91 & 3.38 & 4.59 & 3.4 \\
\cline { 2 - 7 } & D2 & 3.6 & 4.28 & 3.17 & 4.38 & 3.2 \\
\hline
\end{tabular}

Data presented in Table (8) reveal that mean values of water use efficiency seemed to be dependent on quantity of the irrigation water, type of the irrigation system and soil water depletion percentage. Application of the irrigation water at $70 \%$ of ET resulted in higher values of WUE than the other applied quantities i.e. 100\% and 50\% of ET did, where, irrigation at $50 \%$ depletion of the available water resulted in higher values of WUE under the all used irrigation systems and all rates of the applied water except when irrigation water was applied at its lowest ratio i.e. $50 \%$ of ET .Also the irrigation system SD1:1 resulted in the highest mean values of WUE, as compared with the other studied systems . However the interaction between water applied at a rate of $70 \%$ of ET and 50\% depletion of available water under D1:1 irrigation system seemed to be of the highest effect on average value of WUE.

\section{CONCLUSION}

The crop yield is significantly affected by both of applied water quantity and soil water depletion where it was found that decreasing quantity of the applied water significantly decreased crop yield. Centray to that, crop yield in creases by decreasing soil available water deplation. On the other hand, variation in irrigation water system did not significantly affect crop productivity.

\section{REFRENCES}

Ayares, J.E., Schoneman, R.A., Soppe.R.W., Med.R.M.(1998) Irrigation cotton in the presence of shallow ground water .Drainage in the Zist century :food production and the environment, Proc. $7^{\text {th }}$. Int. Drainage Symp. . ASAE,Orlando,FL,March,:p.82-89 
Black, J. N. (1967) The inter relation ship of solar radiation and leaf area index in determining the rate of dry matter production of swards of sub terranean clover (Trifolium sub terranean). Abs. J. Agric. Res., 14:20-38.

Black, J. N. (1965) Method of soil analysis, part 2.No. (9) .Am. Soc. Agron. Inc. pub., Mad., Wise., U.S.A.

Camp, C.R.(1998) Surface drip irrigation : review, Trans. of ASAE 41(5): 1353-1367

Eltantawy,M.T.,H.E.Osman.S.S.,Hassan

,and

S.I.EL-

Khatb(2000)Evaluation of surface Irrigation under perforated pipe on sugarcane in old valley Egypt $8^{\text {th }}$ C. of Misr Soc.,Agr. Eng. 25-26 Oct.:23-33

Jackson, R. D. (1973) Diurnal changes in soil water content. In Field soil water regime. Soil Sci. Soc. Am. Proc. 37: 811, special publication. 5 Sept. - Oct.

Hassan, S.S.A, (1990). The performance of perforated tubes for surface irrigation in small holdings in Egypt, M.Sc.Th., Agric. Eng. Dept., Cairo Univ.

Hutmacher,R.B.,Mead,R.M.,Shouse,P,(1996) Subsurface drip :Improving alfalfa irrigation in the west, Irrg. J.:45.48-52

Kincaid, D.C. (1984) Cablegation.V. : Dimensionless design relation.Tran. Of the ASAE 27(3):679-722

Kohnke, H. (1980) Soil physics soil scientist. Purdue Univ. TATA. Mc Graw Hill. Publishing company Ltd., New Delhi. India., 28-34

Neelan, T.B.S. Rajput (2007) Effect of tape placement depth and irrigation level on yield potato. Agricultural water management 88 : 209-223 Science Direct

Osman ,H.E.(2000)Gated pipes techniques for improved surface irrigation, $8^{\text {th }}$ con. Agric. Dev. Res.Agric., Ain Shams Univ. Cairo November 20-22, 2000 145-155p.

Phene.C.J.,Humatcher,R.B.,McCormick,R.L.,(1987) Advantages of subsurface drip irrigation for processing tomatoes .Acta Hortic.2000.:101-113.

Phene.C.J.,Hutmacher.R.B.,Davis,K.R.,McCormick,R.L.,Meek,D.W. ,(1986)Managementand response of surface drip irrigated 
tomatoes ,Proc. Int: Round 155 Conf. Micro-irrigation ,vol.111Budapest Hungary ,pp.49-56

Richards, L. A. (1954) Diagnosis and improvement of Saline and Alkali soils U.S. salinity lab. Staff. Washington. D. C., U.S.A., Agric. Hand Book No. 60

Smith,R.B.,Oster, J.D.,Phene.C.J.,(1991)Subsurface drip produced the highest net return in the west lands study area. Cal. Agric.45 :810 .

Tekinel,O., Kanber, R.,Koksal,H.,(1999). Irrigationof cotton: Turkish experience .In: proceedings of the first symposium on cotton Agricultural fiber Technology and Textile in Turkish world .Kahramanmar as Turkey.

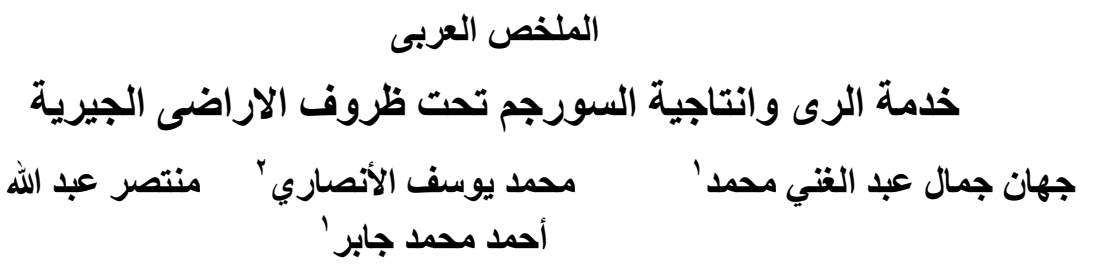

الرى السطحى هو أكثر طرق الرى المستخدمه لامداد المحصول باحتباجاتة المائية انتشارا

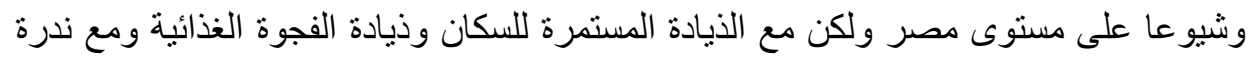

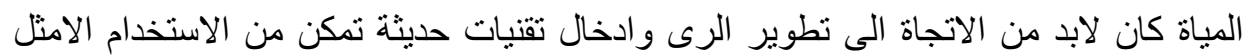

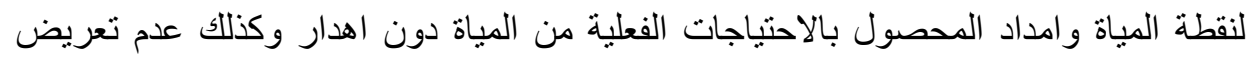

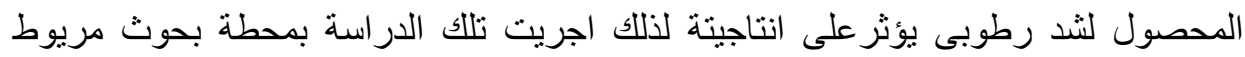

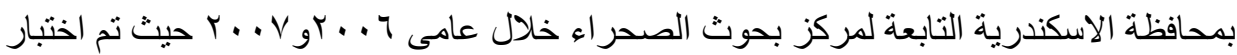

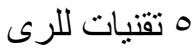

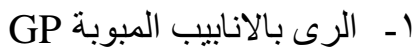

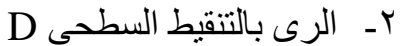
D1:1 أ- خط رى لكل خط نبات
بـ خط رى لكل خطين نبات

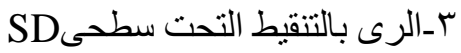
ا-خط رى لكل خط نبات
ب-خط رى لكل خطين نبات SD1:2

1 ـ مركز بحوث الصحر اءء ـ المطرية ـ القاهرة ؟ ـ قسم الهندسة الزراعية ـ كلية الزراعة ـ جامعة بنها 


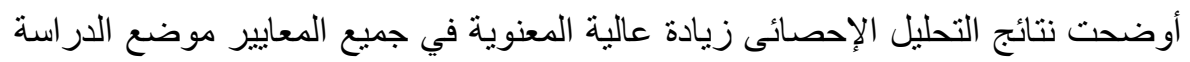

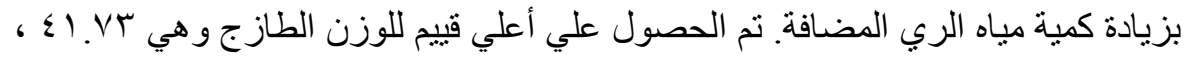

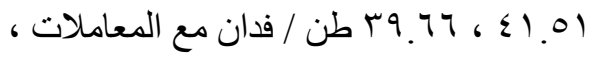

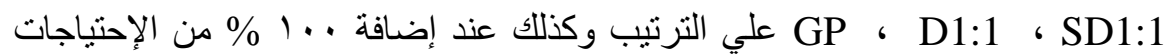

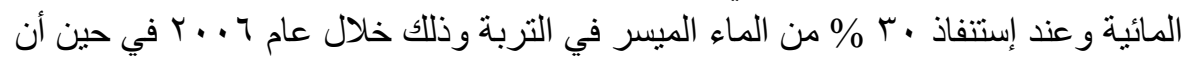

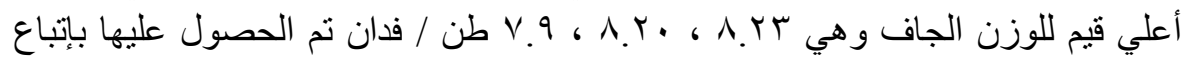

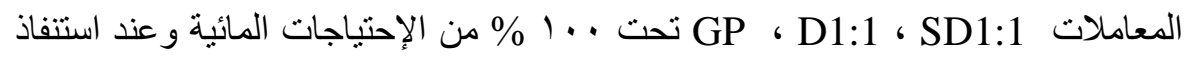

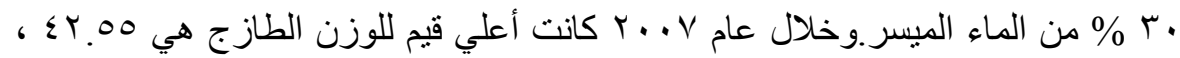

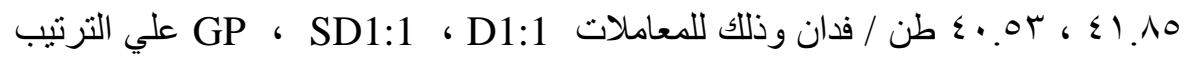

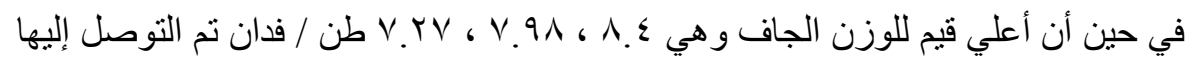

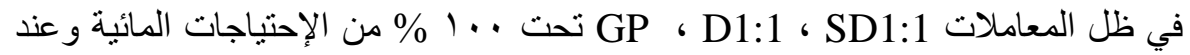

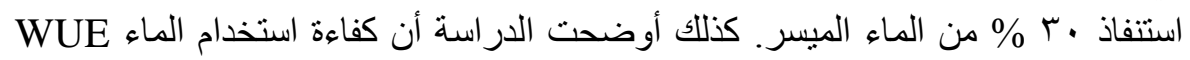
تقل بزيادة كمية الماء المضاف.

التوصيات

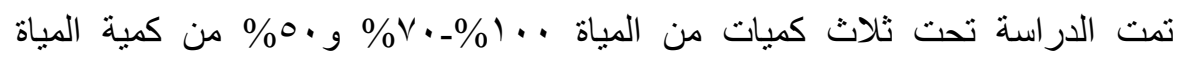

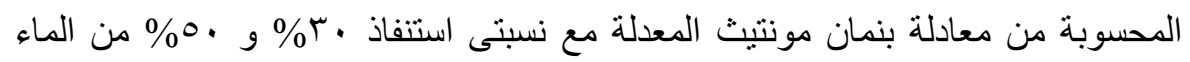

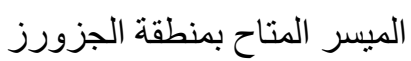

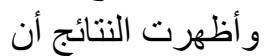

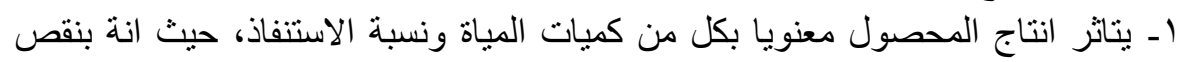

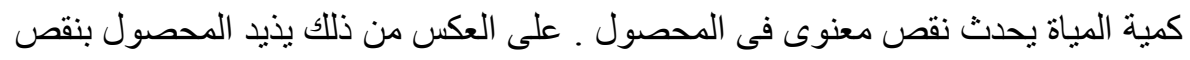

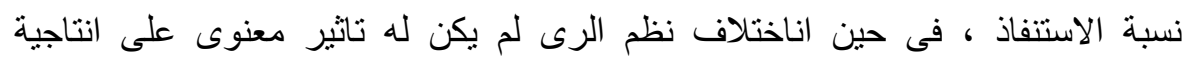

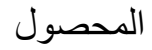

